\title{
The Equivocal Relationship Between Territoriality and Scent Marking in Wild Saddleback Tamarins (Saguinus fuscicollis)
}

\author{
Yvan Lledo-Ferrer • Fernando Peláez • \\ Eckhard W. Heymann
}

Received: 7 September 2010 / Accepted: 25 January 2011 /Published online: 13 April 2011

(C) The Author(s) 2011. This article is published with open access at Springerlink.com

\begin{abstract}
Researchers have often assumed that scent marking serves a territorial function in callitrichines, although some controversy exists. To fulfill such a function, scent marks should 1) prevent intrusions, 2) ensure access to feeding resources, 3) enable avoidance of intergroup encounters, or 4) play an important role in the aggressive encounters between groups. We studied 13 saddleback tamarins (Saguinus fuscicollis) belonging to 3 free-ranging groups, which formed mixed-species troops with moustached tamarins ( $S$. mystax) in the Amazonian rain forest of Peru. None of the predictions were confirmed. The tamarins used a border-marking strategy, marking more on the periphery of their territory. However, feeding trees in overlap and encounter areas received more scent marking but were still visited by neighboring groups. Intergroup encounters occurred more often than expected, and scent-marking frequency was not higher during them than when no other group was present. It appears that instead of defending a territory in the classic sense, the tamarins are optimizing signal transmission by depositing their scents where the probability of detection by neighbors is higher. Saddleback tamarins may use shared areas of their home ranges to exchange information with neighboring groups, perhaps regarding reproductive opportunities.
\end{abstract}

Keywords Callitrichidae $\cdot$ Intergroup encounters · Resource defense $\cdot$ Scent marking · Territoriality

Electronic supplementary material The online version of this article (doi:10.1007/s10764-011-9516-9) contains supplementary material, which is available to authorized users.

Y. Lledo-Ferrer $(\bowtie) \cdot$ E. W. Heymann

Abteilung Verhaltensökologie \& Soziobiologie, Deutsches Primatenzentrum, 37077 Göttingen, Germany

e-mail: yvan.1ledo@uam.es

Y. Lledo-Ferrer · F. Peláez

Área de Psicobiología, Facultad de Psicología, Universidad Autónoma de Madrid, Madrid, Spain 


\section{Introduction}

Olfactory communication is substantially different from other forms of communication, as scent marks are deposited on the substrate, even in the absence of the potential receiver, and can be detected long after they were deposited, even in the absence of the sender (Gosling and Roberts 2001a). Among the several and nonexclusive functions of scent marking in mammals, territorial defense has received much attention. By scent matching, neighbors and intruders may be able to assess territory holders without incurring the costs of direct confrontations (Gosling 1982, 1990; Gosling and McKay 1990). However, a territory holder must maximize the probability of its scents being detected by potential intruders, while reducing the costs of their deposition (Gorman and Mills 1984; Roberts and Lowen 1997). In economically defensible territories, animals should mark along the borders, e.g., Canis latrans (Gese and Ruff 1997), whereas in large territories, a hinterland marking strategy, with scents scattered within the territory, is more efficient, e.g., Suricata suricatta (Jordan et al. 2007).

Chemical signals have been shown to play an important role in maintaining territorial integrity and spacing (Gosling 1982). Scent marks may convey information about competitive ability (Hurst and Beynon 2004), and intruders might assess residents without direct confrontation by scent matching, enabling them to avoid the costs of escalating conflicts (Gosling and Roberts 2001a). In many species, scent marking is a conspicuous part of the aggressive display. Ropartz (1968) found that aggression in Swiss albino mice (Mus musculus) was mediated by olfactory cues, as a reduction of aggression occurred when the natural odors were masked by an artificial scent, and anosmic mice did not display any form of aggressive behavior. Male rabbits (Oryctolagus cuniculus) and male house mice (Mus domesticus) whose scents are present in an experimental arena are more likely to win fights (Gosling and McKay 1990; Mykytowycz et al. 1976). Scent marking is also part of the aggressive display in ring-tailed lemurs (Lemur catta: Gaspari and Crockett 1984). When groups meet, 2 males may anoint their own tails with their own scents, face each other, and wave their tails at one another, which has received the illustrative name of "stink fights" (Jolly 1966).

Olfactory communication is also an important feature of the social lives of marmosets and tamarins. These small-bodied New World Primates, which live in the dense canopy of the Amazonian rain forests, possess a well developed olfactory communication system, with specialized glands in the anogenital, suprapubic, and sternal regions (Epple et al. 1993) and a functional vomeronasal organ (Evans 2003). They can perceive information about species, subspecies, sex, and individual identity in the sender's scent marks (Epple et al. 1993), and females also inform about their reproductive condition through their scents (Washabaugh and Snowdon 1998; Ziegler et al. 1993). These peaceful cooperative breeders (Caine 1993) are nonetheless intolerant toward neighbors or strangers (French and Snowdon 1981; Goldizen 1987), and all group members participate in contests against neighbors (Lazaro-Perea 2001; Peres 1992). However, the intensity of the intergroup interaction varies greatly from severe aggression to peaceful (Buchanan-Smith 1991; Lazaro-Perea 2001), with extragroup copulations possible (Digby 1999). In captivity, scent marking is enhanced when the residents are confronted by strangers 
(French and Snowdon 1981; Harrison and Tardif 1989). Female cottontop tamarins (Saguinus oedipus) increase their anogenital and suprapubic marking frequencies when confronted with strangers (French and Snowdon 1981; Harrison and Tardif 1989). It has been argued that anogenital marking is used in sociosexual contexts, whereas suprapubic marking is performed in situations of aggressive arousal (French and Snowdon 1981). However, researchers have found no functional distinction between the different glands in Saguinus fuscicollis (Belcher et al. 1988).

Although all callitrichid species studied so far possess economically defensible territories (Heymann 2000), their home ranges overlap extensively with each other (Garber et al. 1993). The possible function of scent marking in territorial defense is not clear for callitrichids (Heymann 2006). Apart from Mico intermedius (Rylands 1990), no other species shows a clear border-marking pattern (Heymann 2000; Lazaro-Perea et al. 1999; Miller et al. 2003). Saddleback tamarins (Saguinus fuscicollis) marked the periphery of their home ranges more than the core area, but overall, rates of scent marking were related to patterns of range use (Bartecki and Heymann 1990). Heymann (2000) observed the same in moustached tamarins (Saguinus mystax), where expected and observed rates of scent marking in peripheral and core areas did not differ. The latter study concluded that scent marks do not fulfill a territorial function in this species. Gosling and Roberts (2001b) challenged this conclusion, arguing that the spatial pattern of scent marking should be determined by the distribution of resources in the territory. Indeed, marmosets usually mark gouging holes where they feed on exudates (Lacher et al. 1981; Lazaro-Perea et al. 1999), although a territorial function is unlikely (Rylands 1985). On the other hand, intergroup encounters in mixed-species troops of tamarins take place in the vicinity of major feeding trees, so a resource defense function has been suggested (Garber 1988). Feeding trees can also serve as landmarks for the deposition of the signal (Macdonald 1985).

Scent marking can also serve a territorial defense function during direct encounters with neighboring groups. By definition, 2 groups can meet only in areas of overlap between their home ranges. Therefore, if scent-marking frequency increases during intergroup encounters, it is important to determine if the increase is related to the presence of the neighbor group, or only to the use of an overlap area.

We here reexamine the territorial function of scent marking in a tamarin species, taking the criticism by Gosling and Roberts (2001b) into account. Our study is based on the following predictions: 1) Because saddleback tamarins have economically defensible home ranges, scent marking should be concentrated in peripheral areas (border-marking strategy). 2) If scent marking serves a territorial function in the sense of defense of specific resources, a boundary-marking strategy should be found if resources are homogeneously distributed. If resources are heterogeneous, scent marking should be associated with the resource and related to their size or importance. 3) If scent marking allows avoidance of neighboring groups, then intergroup encounters should occur, at best, on a random basis. 4) If scent marking serves a territorial defense function during intergroup encounters, then we would expect an increase in scent-marking behavior and its investigation during encounters. 


\section{Methods}

\section{Study Site and Focal Groups}

We conducted the study at the Estación Biológica Quebrada Blanco (EBQB) in the Amazonian lowland rain forest of northeastern Peru (Heymann 1995). From May 2007 to June 2008 we followed 3 well habituated groups of Saguinus fuscicollis (Table I) forming mixed-species troops with Saguinus mystax. We observed each saddleback group about 6 consecutive days/mo, from exiting a sleeping site (between 05:15 $\mathrm{h}$ and 06:00 $\mathrm{h}$ ) to retiring to a sleeping site (between 15:30 $\mathrm{h}$ and 16:35 h). All adult subjects were individually recognizable through natural marks, e.g., genital pigmentation, shape of the tail, etc. In addition, we followed 8 neighboring, less habituated groups for a period ranging between 10 and $30 \mathrm{~d}$ from February to September 2008 .

\section{Data Collection}

We recorded scent-marking and olfactory behavior (Table II) via the behavior sampling method (Martin and Bateson 1993). We noted the identity of the individual that scent marked, and whether the scent received any response from other group members. We usually recorded responses to scent marks in the 5 min after deposition because afterwards the group had typically definitively abandoned the area and thus the scent could not receive any further response from other group members (Heymann 1998).

The behavior sampling method can bias the data toward more visible individuals (Martin and Bateson 1993). To correct this bias, we conducted scan samples every $15 \mathrm{~min}$, wherein we recorded the activity of each visible individual within $2 \mathrm{~min}$. Because there were differences in visibility (expected vs. observed representation of individuals in scan samples) between individuals in group $1\left(\chi_{3}^{2}=9.61, p<0.03\right)$

Table I Composition and mating system of the focal groups

\begin{tabular}{llll}
\hline & Group 1 & Group 2 & Group 3 \\
\hline Male, adult & 2 & 4 & 1 \\
Female, adult & $2-1^{\mathrm{a}}$ & 2 & 2 \\
Infant & - & - & $0-1^{\mathrm{b}}-2^{\mathrm{c}}$ \\
Total & $4-3$ & 6 & $3-4-5$ \\
Observation time (h) & 550.4 & 306.4 & 505.8 \\
Mating system & PGA-PA $^{\mathrm{a}}$ & MG & PG \\
\hline
\end{tabular}

${ }^{a}$ One female disappeared between December 21, 2007 and January 5, 2008, while the group was not being observed. The group changed the mating system accordingly

${ }^{\mathrm{b}}$ One infant was born between November 20 and December 1, 2007, and disappeared between December 8, 2007 and January 21, 2008

${ }^{\mathrm{c}}$ Two infants were born between March 7 and 10, 2008

$\mathrm{MG}=$ monogamous; $\mathrm{PA}=$ polyandrous; $\mathrm{PG}=$ =polyginous; $\mathrm{PGA}=$ polyginandrous 
Table II Behavioral coding

\begin{tabular}{ll}
\hline Behavior & Description \\
\hline Scent-marking act & $\begin{array}{l}\text { Completed rubbing movement involving 1 of the } \\
\text { scent glands: anogenital (AG), suprapubic (SP), } \\
\text { or sternal (ST) }\end{array}$ \\
Scent-marking event & $\begin{array}{l}\text { Combination of scent-marking acts (Bartecki and } \\
\text { Heymann 1990) } \\
\text { Overmarking }\end{array}$ \\
$\begin{array}{c}\text { Marking over a previous mark from another } \\
\text { individual }\end{array}$ \\
Scent inspection & $\begin{array}{c}\text { Sniffing, muzzle-rubbing, or licking a scent from } \\
\text { another individual } \\
\text { Oniffing, muzzle-rubbing, or licking the substrate }\end{array}$
\end{tabular}

and in group $2\left(\chi^{2}{ }_{5}=20.87, p<0.001\right)$, we corrected individual scent-marking frequencies by dividing them by the proportion of scans where the respective individual was visible.

We georeferenced scent-marking events on a Garmin etrex GPS, with precision ranging from 10 to $20 \mathrm{~m}$. The location of the group was automatically recorded via the TrackLog option on the GPS. We permanently marked each feeding tree visited by the focal groups with a numbered aluminum tag, georeferenced it, and measured its diameter at breast height (DBH).

We considered an intergroup encounter beginning when 2 groups were in visual contact. However, the behavior of the group is likely to be influenced by the proximity of other groups before and after the encounter itself. Therefore, we included the data from 2 buffer intervals. The first interval begins when the presence of a neighboring group was noticed by the human observers, or since the monkeys started emitting series of long calls, which are usually a prelude to an encounter (Garber et al. 1993; Lazaro-Perea 2001; Terborgh 1983). The second interval includes all data until the group stops emitting long calls (Miller et al. 2003), rests, or abandons the area.

We observed a total of 53 intergroup encounters. We discarded encounters with solitary individuals because these interactions were extremely brief and aggressive, with the intruder fleeing immediately. We considered successive encounters that were separated by $<30 \mathrm{~min}$ as a single encounter in the analysis (Lazaro-Perea 2001). We located the encounter on GPS, and classified it as aggressive if chases and vigorous vocalizations occurred. If the groups stayed in proximity without exchanging behaviors apart from a few vocalizations, we considered the encounter calm. We also recorded extragroup copulations and feeding behavior during encounters.

\section{Data Analysis}

Spatial Analyses We calculated the density of scent-marking events (SME/ha); the intensity of scent-marking (Heymann 2001), defined as the number of scent-marking acts per scent-marking event (SMA/SME); and the number of olfactory inspections per hectare $(\mathrm{OI} / \mathrm{ha})$. We expressed overmarking $(\mathrm{OM})$ and scent inspections (SI) as the proportion of scent-marking acts overmarked or inspected. We calculated feeding 
tree density (no. of trees/ha); and as measures for the importance of the feeding resources, we calculated DBH density (sum of DBH of feeding trees/ha), mean DBH per tree (sum of DBH of feeding trees/no. of feeding trees), and visits per tree (sum of visits to feeding trees/no. of feeding trees).

We compared the observed vs. the expected spatial distribution of scent-marking events based on the intensity of use of the overlap areas (Heymann 2000). We defined home ranges using the $100 \%$ minimum convex polygon (MCP) approach on ArcView GIS 3.3, and identified the overlapping areas, defined as portions of the home range used by $>1$ group. MCPs tend to overestimate the home ranges. This is conservative because scent-marking density would then be underestimated. Moreover, because the neighboring, less habituated groups may not have used their entire home range while being followed, overlap areas might be underestimated.

We defined an encounter area as a 50-m-radius circle around each intergroup encounter, wherever 2 groups established visual contact. We also established another 15-m-radius area around each feeding tree visited, and quantified scent marking within this circle.

We compared the density of scent-marking events, intensity of scent marking, proportion of scent-marking acts inspected and overmarked, and olfactory investigations between exclusive and overlap areas, encounter and overlap areas where no encounter took place, feeding trees in exclusive and overlap areas, feeding trees in encounter and overlap areas, and feeding trees in overlap areas against overlap areas excluding feeding trees. We square-root or log transformed data that did not meet the requirements of normality. We used general linear mixed models (GLMM), with individual identity nested within a group as a random factor; sex, group, and area as fixed factors; and Bonferroni adjustment for multiple comparisons. As one female disappeared from group 1 between December and January, we analyzed data from this group after January 2008 separately.

We compared the distribution of food resources between exclusive and overlap areas, as well as between encounter and overlap areas where no encounter had taken place, and analyzed these with a repeated measures ANOVA.

Intergroup Encounters We compared scent-marking patterns during intergroup encounters to 2 control periods. Because scent marking is strongly influenced by the time of the day (Bartecki and Heymann 1990), we controlled for this variable by recording the behavior of the group $24 \mathrm{~h}$ after the encounter. When these data were not available, e.g., because another encounter was taking place, we considered a period $24 \mathrm{~h}$ previous to the encounter.

To control for variation due to the use of an overlap area, we recorded the behavior of the group in the same area and at the same time of the day, but when no encounter was taking place.

We calculated individual frequencies of scent marking and olfactory exploration by dividing the observed frequencies by the observation time for each phase (Encounter, Next Day, and Same Area). We also calculated the proportion of scentmarking acts deposited with each epidermic gland. We compared scent-marking frequency and intensity, overmarking, scent and olfactory inspections, and the proportion of scent-marking acts deposited with each scent-marking gland across the 
3 phases. We modeled data using general linear mixed models, with individual identity nested within a group as a random factor, and sex, group, and phase as fixed factors. We conducted multiple comparisons with the Bonferroni adjustment. We $\log$-transformed data that were not normally distributed.

We calculated the probability of intergroup encounters with the Waser Gas Model (Waser and Wiley 1979), which assumes that both groups move independently of each other, and that they can meet at any place in space, which is not the case for tamarins that have fixed territories and can meet only at overlap areas. Therefore we used the formula modified by Barrett and Lowen (1998)

$$
f=x \frac{4 p v}{\pi}(s+d)
$$

wherein

$x$ the probability of finding the main study group in the overlap area (when resources are shared, $x=(\mathrm{o} / 2) / \mathrm{e}+(\mathrm{o} / 2) ; \mathrm{o}=$ proportion of overlap area, and $\mathrm{e}=$ proportion of exclusive area)

$\rho$ density of other groups

$v$ group mean velocity

$s$ mean group spread

$d$ approach distance between groups

The parameters used for this calculation are provided as electronic supplementary material.

All tests were 2-tailed and performed in SPSS 16.0.

\section{Results}

Do Saddleback Tamarins Use a Border-marking Strategy?

The focal groups differed in home-range size and in the proportion of home-range overlap (Table III, Fig. 1). Group 1 had the smallest home range and shared 50\% of it with neighbors, whereas group 2 had the largest home range but shared only $21 \%$.

We found an increase in SME in overlap areas vs. the exclusively used areas (Fig. 2; Table IV). Moreover, there was a significant interaction between sex and area (GLMM: $F_{(1,8)}=16.48, p=0.04$ ), wherein females marked more than males in exclusive areas, whereas males marked more in overlap areas. The tamarins marked more in overlap areas than expected by the intensity of use (G1 2007: $G=56.29, \mathrm{df}=1$,

Table III Home-range characteristics of the focal groups

\begin{tabular}{lllll}
\hline Group & Size (ha) & Perimeter (m) & Overlap (ha) & Overlap (\%) \\
\hline 1 & 42.2 & 2397 & 21.3 & 50.4 \\
2 & 80.6 & 3381 & 17 & 21.1 \\
3 & 50.1 & 2590 & 17.4 & 34.6 \\
\hline
\end{tabular}




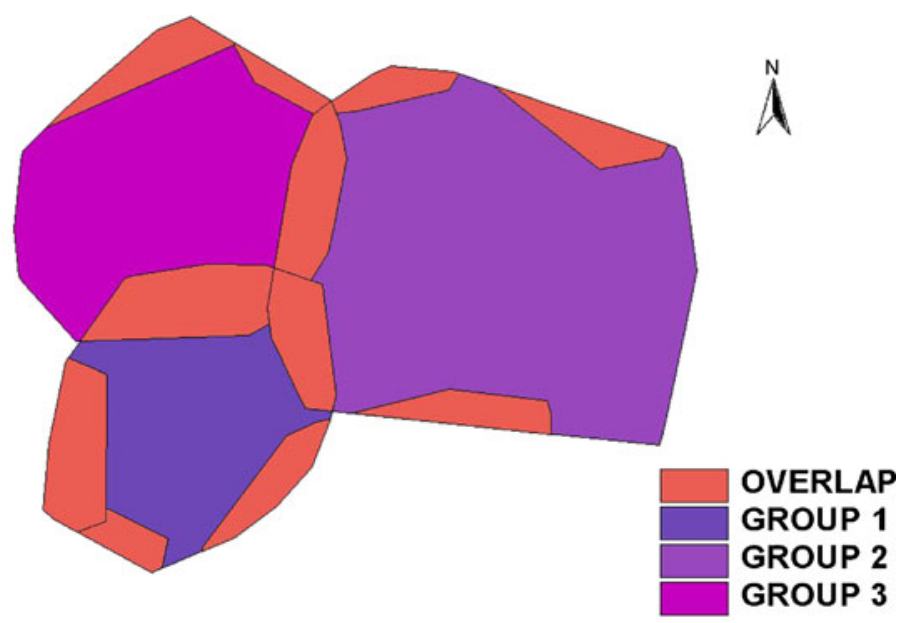

0

1000

2000 Meter

Fig. 1 Home ranges of the focal groups and overlap areas.

$p<0.001$; G1 2008: $G=18.54, \mathrm{df}=1, p<0.001 ; \mathrm{G} 2: G=8.7, \mathrm{df}=1, p<0.004$; G3: $G=37.89, \mathrm{df}=1, p<0.001)$. The intensity of scent marking was higher in overlap areas vs. exclusive areas. There was also a significant interaction between sex and area (GLMM: $F_{(1,11)}=16.04, p=0.002$ ), with males marking more intensely in exclusive areas, whereas females marked more intensely in overlap areas.

Tamarins overmarked the same proportion of scents in exclusive and overlap areas, but inspected the substrate more often per hectare in overlap areas than in exclusive areas. There were more scent-marking events in the area of intergroup encounters vs. overlap areas where no encounter took place, but intensity did not vary. The tamarins overmarked the same proportion of scents in both encounter and

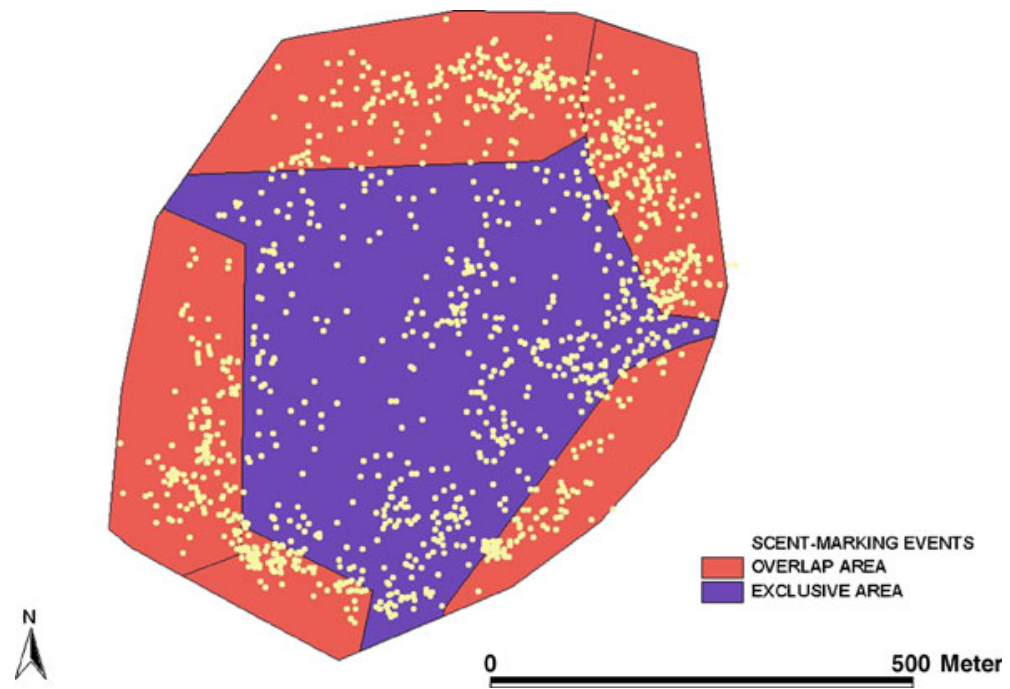

Fig. 2 Distribution of scent-marking events (group 1). 
Table IV Summary of results of the spatial analyses

\begin{tabular}{|c|c|c|c|c|}
\hline Comparison & SME & Intensity & Overmarking & Olfactory inspection \\
\hline \multirow[t]{3}{*}{ Exclusive vs. overlap } & Overlap>exclusive & Overlap $>$ exclusive & Overlap $=$ exclusive & Overlap $>$ exclusive \\
\hline & $\begin{array}{c}17.7 \pm 0.56 \text { vs } \\
14.41 \pm 0.56\end{array}$ & $\begin{array}{l}2.31 \pm 0.05 \text { vs. } \\
1.98 \pm 0.05\end{array}$ & $\begin{array}{l}0.11 \pm 0.01 \text { vs. } \\
0.10 \pm 0.01\end{array}$ & $\begin{array}{l}8.01 \pm 0.59 \text { vs. } \\
5.61 \pm 0.59\end{array}$ \\
\hline & $\begin{array}{l}F_{(1,8)}=53.98 \\
\quad p<0.001\end{array}$ & $\begin{array}{l}F_{(1,8)}=102.95 \\
\quad p<0.001\end{array}$ & $\begin{array}{c}F_{(1,15)}=1.4 \\
p=0.26\end{array}$ & $\begin{array}{l}F_{(1,8)}=24.16 \\
\quad p=0.01\end{array}$ \\
\hline \multirow[t]{3}{*}{ Encounter vs. overlap } & Encounter $>$ overlap & Encounter $=$ overlap & Encounter $=$ overlap & Encounter $>$ overlap \\
\hline & $\begin{array}{c}2.79 \pm 0.07 \text { vs. } \\
1.26 \pm 0.06\end{array}$ & $\begin{array}{l}2.17 \pm 0.1 \text { vs. } \\
2.31 \pm 0.1\end{array}$ & $\begin{array}{c}0.11 \pm 0.01 \text { vs. } \\
0.11 \pm 0.01\end{array}$ & $\begin{array}{c}1.81 \pm 0.21 \mathrm{vs} . \\
1.01 \pm 0.021\end{array}$ \\
\hline & $\begin{array}{l}F_{(1,13.14)}=360.57 \\
\quad p<0.001\end{array}$ & $\begin{array}{l}F_{(1,15.66)}=1.6 \\
p=0.22\end{array}$ & $\begin{array}{l}F_{(1,15.32)}=0.06 \\
p=0.81\end{array}$ & $\begin{array}{l}F_{(1,15.39)}=8.69 \\
p=0.01\end{array}$ \\
\hline \multirow{3}{*}{$\begin{array}{l}\text { Tree exclusive vs. } \\
\text { tree overlap }\end{array}$} & Overlap>exclusive & Overlap > exclusive & Overlap $\geq$ exclusive & Overlap > exclusive \\
\hline & $\begin{array}{c}39.55 \pm 2.02 \text { vs. } \\
19.59 \pm 2.02\end{array}$ & $\begin{array}{l}2.44 \pm 0.06 \text { vs. } \\
1.87 \pm 0.06\end{array}$ & $\begin{array}{l}0.31 \pm 0.02 \text { vs. } \\
0.27 \pm 0.02\end{array}$ & $\begin{array}{l}20.55 \pm 1.65 \text { vs. } \\
\quad 9.16 \pm 1.65\end{array}$ \\
\hline & $\begin{array}{l}F_{(1,8)}=69.76 \\
p<0.001\end{array}$ & $\begin{array}{l}F_{(1,8)}=131.84 \\
\quad p<0.001\end{array}$ & $\begin{array}{c}F_{(1,15)}=3.88 \\
p=0.068\end{array}$ & $\begin{array}{l}F_{(1,8)}=26.05 \\
p=0.001\end{array}$ \\
\hline \multirow{3}{*}{$\begin{array}{l}\text { Tree encounter vs. } \\
\text { tree overlap }\end{array}$} & Encounter $>$ overlap & Encounter $=$ overlap & Encounter $=$ overlap & Encounter $>$ overlap \\
\hline & $\begin{array}{l}17.95 \pm 0.51 \text { vs. } \\
8.48 \pm 0.51\end{array}$ & $\begin{array}{l}2.51 \pm 0.13 \text { vs. } \\
2.33 \pm 0.13\end{array}$ & $\begin{array}{l}0.12 \pm 0.01 \text { vs. } \\
0.10 \pm 0.01\end{array}$ & $\begin{array}{c}0.03 \pm 0.004 \mathrm{vs} \\
0.02 \pm 0.004\end{array}$ \\
\hline & $\begin{array}{l}F_{(1,8)}=179.02 \\
\quad p<0.001\end{array}$ & $\begin{array}{l}F_{(1,8)}=2.39 \\
\quad p=0.16\end{array}$ & $\begin{array}{l}F_{(1,15)}=1.04 \\
\quad p=0.32\end{array}$ & $\begin{array}{c}F_{(1,8)}=78.31 \\
p<0.001\end{array}$ \\
\hline \multirow{3}{*}{$\begin{array}{l}\text { Tree overlap vs. overlap } \\
\text { excluding trees }\end{array}$} & Tree>overlap & Tree $\geq$ overlap & Tree= overlap & Tree>overlap \\
\hline & $\begin{array}{c}3.37 \pm 0.08 \text { vs. } \\
1.88 \pm 0.08\end{array}$ & $\begin{array}{c}0.86 \pm 0.05 \text { vs. } \\
0.73 \pm 0.05\end{array}$ & $\begin{array}{c}0.13 \pm 0.01 \mathrm{vs} \\
0.12 \pm 0.01\end{array}$ & $\begin{array}{c}1.79 \pm 0.15 \mathrm{vs} \\
0.42 \pm 0.15\end{array}$ \\
\hline & $\begin{array}{l}F_{(1,11.53)}=218.31 \\
\quad p<0.001\end{array}$ & $\begin{array}{c}F_{(1,17.19)}=3.16 \\
p=0.09\end{array}$ & $\begin{array}{l}F_{(1,14.54)}=1.94 \\
p=0.18\end{array}$ & $\begin{array}{l}F_{(1,10.97)}=48.65 \\
\quad p<0.001\end{array}$ \\
\hline
\end{tabular}

overlap areas. However, the subjects inspected the substrate more in encounter areas than in overlap areas.

How are Resources Distributed and Scent Marked?

Trees in overlap areas received more SME than in exclusive areas, and the subjects scent marked more intensely (Table IV). The tamarins inspected the substrate close to trees in overlap areas more than in exclusive areas. We found a trend for higher proportion of overmarking in trees in overlap areas vs. trees in exclusive areas.

Trees in the encounter area received more SME than in the overlap area, but the intensity of scent marking did not change. The tamarins performed more olfactory investigations in trees in the encounter area. There was no difference in the proportion of scent marks that were overmarked.

Trees in overlap areas also received more SME than overlap areas with no feeding trees in proximity, and there was a trend for higher intensity. The tamarins also inspected the substrate more often near feeding trees than in the rest of the overlap area, but there are no differences in the proportion of scents overmarked. 
There are no differences in tree density (ANOVA: $F_{(1,4)}=1.23, p=0.33$ ), DBH density (ANOVA: $F_{(1,4)}=1.56, p=0.28$ ), DBH per tree (ANOVA: $F_{(1,4)}=0.31, p=0.61$ ), or visits per tree (ANOVA: $F_{(1,4)}=0.04, p=0.85$ ) between exclusive and overlap areas. Moreover, there are also no differences between overlap and encounter areas in tree density (ANOVA: $F_{(1,4)}=0.004, p=0.95$ ), DBH density (ANOVA: $F_{(1,4)}=$ $0.016, p=0.77$ ), DBH per tree (ANOVA: $F_{(1,4)}=4.02, p=0.12$ ), or visits per tree (ANOVA: $F_{(1,4)}=0.35, p=0.59$ ).

\section{Do Intergroup Encounters Occur on a Chance Basis?}

We observed a total of 53 intergroup encounters. Group 1 had 37 encounters $(0.55$ encounters/d), group 2 had $7(0.18 / d)$, and group 3 was involved in $9(0.15 / d)$. The mean duration of encounters was $14 \mathrm{~min}( \pm 17)$, with a minimum duration of $1 \mathrm{~min}$ and a maximum of $86 \mathrm{~min}$.

According to Waser's Gas Model, the probability of groups meeting each other was higher than expected if they had moved independently (Fig. 3). We classified $41 \%$ of these encounters as calm and $59 \%$ as aggressive. Independently of the classification of the encounter, we observed males herding females from their own group right before or during the encounter in $65 \%$ of cases. We observed 3 extrapair copulations and 3 genital inspections that did not lead to copulation. Finally, on 7 occasions we observed individuals feeding without interruption by the other group, during both calm and aggressive intergroup encounters.

\section{Do Saddleback Tamarins Scent Mark More During Intergroup Encounters?}

Phase had a significant effect on the frequency of SME (GLMM: $F_{(2,28)}=6.14, p=$ 0.006; Fig. 4a). Post hoc comparisons revealed that scent-marking frequency was higher during encounters than on the next day $(p=0.007)$, but did not differ from the same area $(p=1)$. Females tended to mark more than males in all phases, although this is not statistically significant $\left(F_{(1,14)}=3.2, p<0.10\right)$.

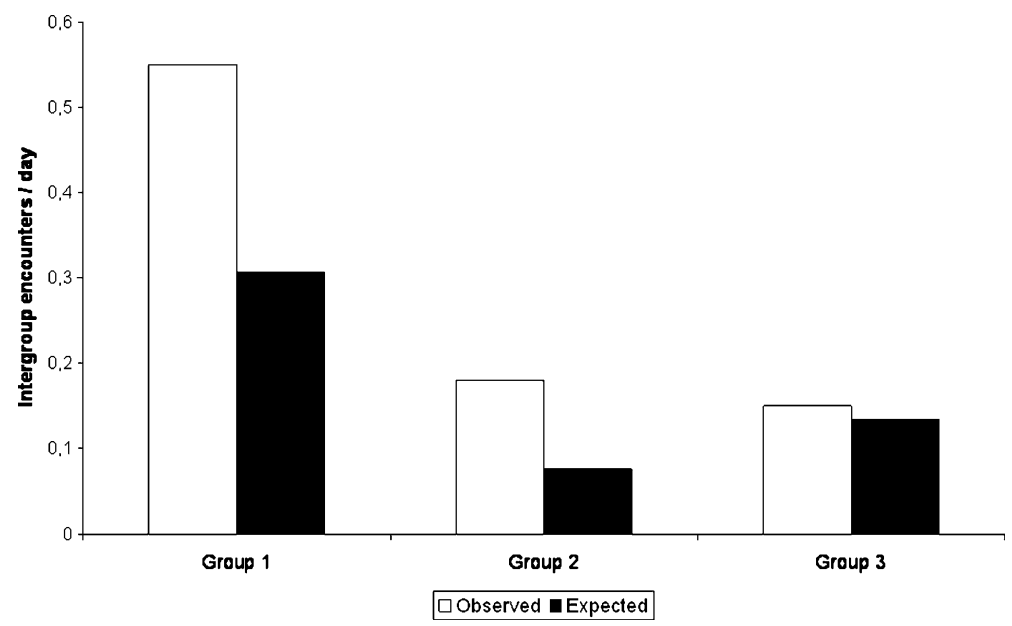

Fig. 3 Observed vs. expected frequency of intergroup encounters based on Waser's Gas Model. 


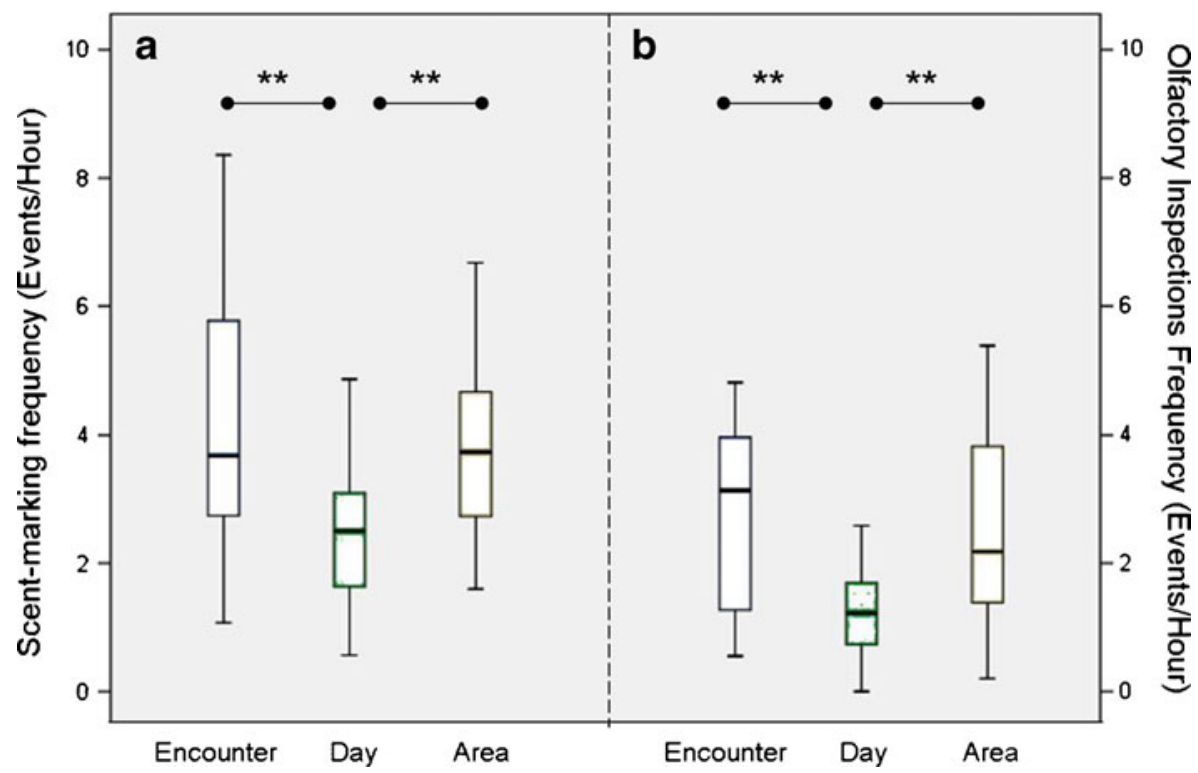

Fig. 4 Scent-marking frequency a and frequency of olfactory inspections $\mathbf{b}$ during intergroup encounters, $24 \mathrm{~h}$ later (Day), and when the group uses the same area of the encounter (Area), but no other group is present. $* * p<0.01$.

The use of the different scent glands did not differ between phases (proportion of AG: GLMM: $\left.F_{(2,24)}=0.21, p=0.11\right)$. The intensity of scent marking was independent of phase (GLMM: $\left.F_{(2,28)}=0.03, p=0.97\right)$ and sex $\left(\mathrm{GLMM}: F_{(1,14)}=0.00, p=0.99\right)$.

Phase had a significant effect on the proportion of scents inspected by group mates (GLMM: $\left.F_{(2,30)}=3.6, p=0.04\right)$. Post hoc comparisons revealed a tendency for a lower proportion of scents to be investigated during intergroup encounters vs. the same area (Bonferroni $p=0.059$; Fig. $4 \mathrm{~b}$ ). There was no difference in the proportion of scent-marking acts that were overmarked by group mates $\left(\operatorname{GLMM}: F_{(2,22)}=0.01\right.$, $p=0.99$ ). Only 4 times did we observe a scent receiving a response from a member of the neighboring group during an intergroup encounter.

Phase had a significant effect on the frequency of olfactory inspections (GLMM: $\left.F_{(2,28)}=6.96, p=0.004\right)$. This frequency was significantly lower during intergroup encounters vs. the next day (Bonferroni $p=0.005$; Fig. 5), but did not differ compared with the use of the same area (Bonferroni $p=1$ ).

\section{Discussion}

We found a clear border-marking strategy, which is consistent with an economically defensible home range. The tamarins deposited more scent marks and marked with higher intensity in overlap areas, and this marking pattern could not be explained by a higher intensity of use of these areas. These results are in line with those of Bartecki and Heymann (1990), who demonstrated that saddleback tamarins marked more on the periphery at the same study site. However, our results contrast sharply with those of Heymann (2000), who did not find a definite spatial pattern of scent 
Fig. 5 Proportion of a group's own scents inspected during intergroup encounters, $24 \mathrm{~h}$ later (Day), and when the group uses the same area of the encounter (Area), but no other group is present.

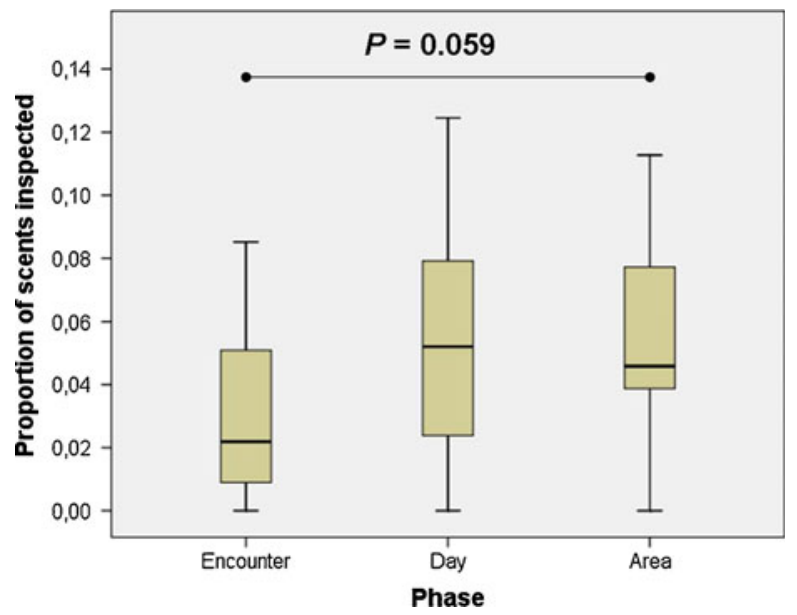

marking in sympatric moustached tamarins, although they invest more in boundary contests than saddlebacks (Peres 1992). This different pattern of scent marking cannot be accounted for by feeding ecology, as the 2 species share $75-90 \%$ of their vegetable diet (Knogge and Heymann 2003), and both studies were conducted at the same study site. Moreover, the limiting factor for tamarins is not their vegetable diet but the animal prey (Smith 2000). Indeed, animal prey is defended by depletion, and capture success in saddleback tamarins is significantly lower at the periphery of their home range (Peres 1992).

Overlap areas received more scent-marking events than exclusive areas and the areas around intergroup encounters more than other shared areas where no encounter had taken place. However, as Gosling and Roberts (2001b, F7) noted: "it is difficult to ascribe a function to a signal without some direct indication of the benefits that accrue to the signaller." One possible benefit may be related to the exclusion of intruders. However, the large overlap between territories shows that scent marks are not effective in maintaining spatial exclusivity and preventing intrusions.

Another possible benefit might be related to the defense of especially valuable resources. Feeding trees in overlap areas received more scent-marking events and a higher scent-marking intensity than those in exclusive areas. When comparing the distribution of scents within the overlap area, we found that feeding trees received more scent-marking events and a slightly higher intensity of scent-marking than the rest of the overlap area. Feeding trees in the encounter areas also received more scentmarking events vs. feeding trees on other overlap areas where no encounter had taken place. Researchers have also reported this enhanced marking in food resources in Callithrix jacchus (Lazaro-Perea et al. 1999), C. penicillata (Lacher et al. 1981), Mico intermedius (Rylands 1985), and Leontopithecus rosalia (Miller et al. 2003).

At first sight, this could be interpreted as evidence for a resource defense strategy, if major feeding trees were located close to intergroup encounters (Garber 1988). However, we found resources to be homogeneously distributed, so a boundarymarking strategy would be more appropriate, with no need for direct, additional marking close to the resource. Further, this strategy does not seem to be effective because we observed different groups feeding on the same trees on different days, or 
during intergroup encounters. Moreover, overmarking other group members seems counterproductive because it reduces the probability of the mark being detected compared to 2 separate marks.

One of the proposed functions of overmarking is signaling competitive ability of territory owners (Ferkin and Pierce 2007; Gosling and Roberts 2001a). This does not seem to be the primary function in saddleback tamarins. The perception of these overmarks does not restrain intruders from feeding because monkeys feed even during intergroup encounters, without interference from the other group. Moreover, as intergroup encounters happened more often than expected by chance, the groups do not avoid confrontations. Thus, the tamarins may instead be using the information contained in the neighbors' scents to search for them, as suggested for marmosets (Lazaro-Perea 2001; Lazaro-Perea et al. 1999; 2000).

Chemical communication has been said to play an important role in territorial agonistic behavior, as captive tamarins increase their scent-marking rates when confronted with intruders (Epple 1980; Epple and Alveario 1985; French and Snowdon 1981). Our groups increased their scent-marking frequency during intergroup encounters vs. $24 \mathrm{~h}$ later. However, this increase was not related to the encounter with another group per se, as we found no difference in scent-marking frequency in areas of intergroup encounters, and the same shared area of the home range, when no other group was present.

The proportion of scents deposited with each gland did not vary, in contrast to those in cottontop tamarins (French and Snowdon 1981) and ring-tailed lemurs (Palagi and Norscia 2009). It could be argued that saddleback tamarins do not show a functional distinction between the anogenital and the suprapubic gland (Belcher et al. 1988). However, it seems puzzling that 2 anatomically different glands transmit redundant information. It could also be that different glands do indeed transmit different kinds of information, but that the tamarins transmit them all at a time (Lazaro-Perea 2001), or that different combinations of scent-marking acts from different glands within an event do transmit a different message.

During intergroup encounters the subjects tended to be less interested in their own group scents than in the same area when no other group was present. This may be explained by the nature of these intergroup encounters, wherein individuals spread over a large area and are often aggressively chased by neighbors. Thus, actively monitoring group mates may be difficult in these conditions. But despite this decrease in scent inspections, the proportion of scents overmarked did not vary, which suggests that the tamarins nevertheless knew where the scents had been deposited, possibly via volatile cues.

One way to obtain the information transmitted by neighbors is by direct inspection of the substrate. Ideally, focal scent marks should be monitored, which was not possible in our study. We observed only 4 scents receiving a response from the neighboring group. Some other scents, unnoticed by the human observer, may nevertheless have been inspected. An indirect way of evaluating this possibility is by substrate inspection. Although the tamarins inspected the substrate with a higher frequency during intergroup encounters vs. the next day, this was again related to the use of an overlap area.

Olfactory communication does not seem to play a major role in the intergroup encounters of wild saddleback tamarins, in contrast to captive settings (Epple et al. 
1993). Indeed, in the wild neighbors are not complete strangers but rather dear enemies (Temeles 1994). Moreover, scent marking is not a very effective communication channel owing to its poor directionality and slow transmission speed (Endler 1993). It is thus not well suited for intergroup encounters in callitrichids, which are characterized by vocal exchanges, chases, and frenetic activity. Thus, if scent marking does not prevent intrusions in the territory, does not ensure exclusive access to resources, does not prevent territorial contests, and does not play a major role during intergroup encounters, does it have a function at all?

Most studies on territoriality have considered only deposition of the signal, neglecting its reception (cf. Gosling et al. 1996a, b; Palagi and Norscia 2009), which gives an incomplete picture of the communication process (Kappeler 1998). Tamarins performed more olfactory inspections in overlap areas and close to feeding trees in these areas. These results are the logical counterpart of the increased scent density reported. If the neighboring groups are also extensive and intensively marking these areas, the focal group could be trying to gain as much information as possible by inspecting the substrate where other groups may have deposited a large amount of scents as well.

Tamarins might then be optimizing signal transmission by marking where the probability of perception by other groups is higher, an economic strategy also described in antelopes (Brashares and Arcese 1999) and in ring-tailed lemurs (Palagi and Norscia 2009). In contrast to terrestrial mammals, in the dense, humid, 3dimensional environment of callitrichid monkeys, the probability of detecting a scent from other group may be extremely low, and the signal may vanish quickly (Epple et al. 1980). The latter might be overridden by an enhanced intensity of scent marking as seen in our study, while marking where the probability of finding an audience is higher may partially override the former.

Thus, feeding trees in overlap areas may be a type of bulletin board, where individuals from different groups exchange information. A similar function was suggested for the gouging holes of common marmosets, but only in intragroup communication (Lazaro-Perea et al. 1997; Rylands 1985). The spatial pattern revealed by our study suggests, instead, that it serves for intergroup communication. Indeed, feeding trees in overlap areas may be visited by different groups within the same day, just as gouging holes in marmosets (Lacher et al. 1981). We observed several times the tamarins marking fruits from Wettinia augusta, without consuming them, which would have obliterated the message. However, they fed on those trees on previous and subsequent days (see video on electronic supplementary material).

If overlap areas enable chemical information exchange between groups, it may be asked which kind of information is to be transmitted. The fact that the scent-marking pattern varies between males and females suggests that this information might be related to mating competition. Males deposited more scents in overlap areas than females did, whereas females marked more intensely. In another study, we found that scent-marking frequency correlates with copulations in males, while intensity of scent marking correlates with copulation in females (Lledo-Ferrer et al. in prep.). It thus seems that both males and females perform scent marking in overlap areas in such a way that key features for mate choice might be detected by extragroup individuals. Indeed, extragroup copulations are common, which might explain the herding behavior observed. Moreover, males overmark females and vice versa 
(Lledo-Ferrer et al. in prep.), which suggests that overmarking may be a way of concealing chemical information, as in antelopes (Brashares and Arcese 1999; Roberts and Dunbar 2000), instead of ensuring predominance for scent matching.

Reproductive constraints are extremely heavy on callitrichids. Not only do most males delay breeding in their groups (Goldizen and Terborgh 1989), but fewer than half of the females reach a reproductive position, as the number of adult females is higher than the number of reproductive positions (Goldizen et al. 1996). Thus, scent marks may allow individuals to determine which neighboring groups to meet and with what frequency to explore reproductive opportunities or to achieve extragroup copulations. Intergroup encounters may then rather be the dénouement of this continuous monitoring and allow a visual, direct evaluation of neighbors (Lazaro-Perea 2001; see the "fight to learn" hypothesis: Getty 1989).

Even if further research, and larger sample size, is needed to determine how group size, sex ratio, and mating system influence scent-marking behavior, our results are not likely to represent group idiosyncrasies. First, our results are in line with Bartecki and Heymann's (1990), whose saddleback tamarins marked more on the periphery at the same study site. Second, our focal groups represented all possible mating systems (Table I).

If scent marks are intended to exchange reproductive information between groups, the differences in the patterns of olfactory communication between Saguinus fuscicollis and $S$. mystax may reflect subtle yet important differences in the mating system of the species (Heymann 2001). Huck et al. (2005) found a high intragroup relatedness in moustached tamarins at the EBQB study site, but mating partners were not closely related and 1 extragroup paternity was detected. Moreover, partners usually did not share the same haplotype (Huck et al. 2007), which suggests that there is regular outbreeding. We hypothesize that relatedness among saddleback tamarins may be higher than among moustached tamarins, which would put a higher premium on the former to look for reproductive opportunities in neighboring groups.

Acknowledgments We thank the Instituto Nacional de Recursos Naturales in Lima for the authorization to carry out field studies at the EBQB (authorization no. 106-2007-INRENA-IFFS-DCB), our field assistants Ney Shahuano Tello and Aladino Hidalgo, and Paloma Nuche for help in data collection. Conny Kraus patiently provided statistical advice. Y. Lledo-Ferrer thanks Fundación La Caixa and Fundación Cajamadrid for personal grants, the Spanish Ministry for Education and Science (MEC-DGI contract grant no. SEJ2005-00016), and the Ministry for Science and Innovation (MCINN-SGPI contract grant no. PSI2009-08581PSIC). We also thank the reviewers who helped to improve the original manuscript.

Open Access This article is distributed under the terms of the Creative Commons Attribution Noncommercial License which permits any noncommercial use, distribution, and reproduction in any medium, provided the original author(s) and source are credited.

\section{References}

Barrett, L., \& Lowen, C. B. (1998). Random walks and the gas model: spacing behaviour of grey-cheeked mangabeys. Functional Ecology, 12, 857-865.

Bartecki, U., \& Heymann, E. W. (1990). Field observations on scent-marking behavior in saddle-back tamarins, Saguinus fuscicollis (Callitrichidae, Primates). Journal of Zoology, 220, 87-99. 
Belcher, A., Epple, G., Kuderling, I., \& Smith, A. B. (1988). Volatile components of scent material from cotton-top tamarin (Saguinus oedipus oedipus) - a chemical and behavioral study. Journal of Chemical Ecology, 14, 1367-1384.

Brashares, J., \& Arcese, P. (1999). Scent marking in a territorial African antelope. II. The economics of marking with faeces. Animal Behaviour, 57, 11-17.

Buchanan-Smith, H. M. (1991). Encounters between neighbouring mixed species groups of tamarins in Northern Bolivia. Primate Report, 31, 95-100.

Caine, N. G. (1993). Flexibility and co-operation as unifying themes in Saguinus social organization and behaviour: The role of predation pressures. In A. B. Rylands (Ed.), Marmosets and tamarins: Systematics, behaviour, and ecology (pp. 200-219). Oxford: Oxford University Press.

Digby, L. J. (1999). Sexual behavior and extragroup copulations in a wild population of common marmosets (Callithrix jacchus). Folia Primatologica, 70, 136-145.

Endler, J. A. (1993). Some general comments on the evolution and design of animal communication systems. Philosophical Transactions of the Royal Society of London. Series B: Biological Sciences, 340, 215-225.

Epple, G. (1980). Relationships between aggression, scent marking and gonadal state in a primate, the tamarin Saguinus fuscicollis. In D. Mueller-Schwarze \& R. M. Silverstein (Eds.), Chemical signals: Vertebrates and aquatic invertebrates (pp. 87-105). New York: Plenum Press.

Epple, G., \& Alveario, M. C. (1985). Social facilitation of agonistic responses to strangers in pairs of saddle back tamarins (Saguinus fuscicollis). American Journal of Primatology, 9, 207-218.

Epple, G., Alveario, M. C., Golob, N. F., \& Smith, A. B. (1980). Stability and attractiveness related to age of scent marks of saddleback tamarins (Saguinus fuscicollis). Journal of Chemical Ecology, 6, 735-748.

Epple, G., Belcher, A. M., Küderling, I., Zeller, U., Scolnick, L., Greenfield, K. L., et al. (1993). Making sense out of scents: Species differences in scent glands, scent-marking behaviour, and scent-mark composition in the Callitrichidae. In A. B. Rylands (Ed.), Marmosets and tamarins: Systematics, behaviour, and ecology (pp. 123-151). Oxford: Oxford University Press.

Evans, C. S. (Ed.). (2003). Vomeronasal chemoreception in vertebrates: A study of the second nose. London: Imperial College Press.

Ferkin, M. H., \& Pierce, A. A. (2007). Perspectives on over-marking: is it good to be on top? Journal of Ethology, 25, 107-116.

French, J. A., \& Snowdon, C. T. (1981). Sexual dimorphism in responses to unfamiliar intruders in the tamarin, Saguinus oedipus. Animal Behaviour, 29, 822-829.

Garber, P. A. (1988). Diet, foraging patterns, and resource defense in a mixed species troop of Saguinus mystax and Saguinus fuscicollis in Amazonian Peru. Behaviour, 105, 18-34.

Garber, P. A., Pruetz, J. D., \& Isaacson, J. (1993). Patterns of range use, range defense, and intergroup spacing in moustached tamarin monkeys (Saguinus mystax). Primates, 34, 11-25.

Gaspari, M. K., \& Crockett, C. M. (1984). The role of scent marking in Lemur catta agonistic behavior. Zoo Biology, 3, 123-132.

Gese, E. M., \& Ruff, R. L. (1997). Scent-marking by coyotes, Canis latrans: the influence of social and ecological factors. Animal Behaviour, 54, 1155-1166.

Getty, T. (1989). Are dear enemies in a war of attrition? Animal Behaviour, 37, 337-339.

Goldizen, A. W. (1987). Tamarins and marmosets: Communal care of offspring. In B. B. Smuts, D. L. Cheney, R. M. Seyfarth, R. W. Wrangham, \& T. T. Struhsaker (Eds.), Primate societies (pp. 34-43). Chicago: University of Chicago Press.

Goldizen, A. W., Mendelson, J., van Vlaardingen, M., \& Terborgh, J. (1996). Saddle-back tamarin (Saguinus fuscicollis) reproductive strategies: evidence from a thirteen-year study of a marked population. American Journal of Primatology, 38, 57-83.

Goldizen, A. W., \& Terborgh, J. (1989). Demography and dispersal patterns of a tamarin populationpossible causes of delayed breeding. The American Naturalist, 134, 208-224.

Gorman, M., \& Mills, M. (1984). Scent marking strategies in hyaenas (Mammalia). Journal of Zoology, 202, 535-547.

Gosling, L. M. (1982). A reassessment of the function of scent marking in territories. Zeitschrift für Tierpsychologie, 60, 89-118.

Gosling, L. M. (1990). Scent marking by resource holders: Alternative mechanisms for advertising the costs of competition. In D. W. Macdonald, D. Mueller-Schwarze, \& S. E. Natynczuk (Eds.), Chemical signals in vertebrates (pp. 315-328). Oxford: Oxford University Press.

Gosling, L. M., Atkinson, N., Collins, S., Roberts, R., \& Walters, R. (1996a). Avoidance of scent-marked areas depends on the intruder's body size. Behaviour, 133, 491-502.

Gosling, L. M., Atkinson, N., Dunn, S., \& Collins, S. (1996b). The response of subordinate male mice to scent marks varies in relation to their own competitive ability. Animal Behaviour, 52, 1185-1191. 
Gosling, L. M., \& McKay, H. V. (1990). Competitor assessment by scent matching — an experimental test. Behavioral Ecology and Sociobiology, 26, 415-420.

Gosling, L. M., \& Roberts, S. C. (2001a). Scent-marking by male mammals: Cheat-proof signals to competitors and mates. In P. Slater (Ed.), Advances in the study of behavior (pp. 169-217). San Diego: Academic Press.

Gosling, L. M., \& Roberts, S. C. (2001b). Testing ideas about the function of scent marks in territories from spatial patterns. Animal Behaviour, 62, F7-F10.

Harrison, M. L., \& Tardif, S. D. (1989). Species differences in response to conspecific intruders in Callithrix jacchus and Saguinus oedipus. International Journal of Primatology, 10, 343-362.

Heymann, E. W. (1995). Sleeping habits of tamarins, Saguinus mystax and Saguinus fuscicollis (Mammalia; Primates; Callitrichidae), in north-eastern Peru. Journal of Zoology, 237, 211-226.

Heymann, E. W. (1998). Sex differences in olfactory communication in a primate, the moustached tamarin, Saguinus mystax (Callitrichinae). Behavioral Ecology and Sociobiology, 43, 37-45.

Heymann, E. W. (2000). Spatial patterns of scent marking in wild moustached tamarins, Saguinus mystax: No evidence for a territorial function. Animal Behaviour, 60, 723-730.

Heymann, E. W. (2001). Interspecific variation of scent-marking behaviour in wild tamarins, Saguinus mystax and Saguinus fuscicollis. Folia Primatologica, 72, 253-267.

Heymann, E. W. (2006). Scent marking strategies of new world primates. American Journal of Primatology, 68, 650-661.

Huck, M., Löttker, P., Bohle, U. R., \& Heymann, E. W. (2005). Paternity and kinship patterns in polyandrous moustached tamarins (Saguinus mystax). American Journal of Physical Anthropology, 127, 449-464.

Huck, M., Roos, C., \& Heymann, E. W. (2007). Spatio-genetic population structure in mustached tamarins, Saguinus mystax. American Journal of Physical Anthropology, 132, 576-583.

Hurst, J. L., \& Beynon, R. J. (2004). Scent wars: the chemobiology of competitive signaling in mice. BioEssays, 26, 1288-1298.

Jolly, A. (1966). Lemur behavior: A Madagascar field study. Chicago: University of Chicago Press.

Jordan, N. R., Cherry, M. I., \& Manser, M. B. (2007). Latrine distribution and patterns of use by wild meerkats: implications for territory and mate defence. Animal Behaviour, 73, 613-622.

Kappeler, P. M. (1998). To whom it may concern: the transmission and function of chemical signals in Lemur catta. Behavioral Ecology and Sociobiology, 42, 411-421.

Knogge, C., \& Heymann, E. W. (2003). Seed dispersal by sympatric tamarins, Saguinus mystax and Saguinus fuscicollis: diversity and characteristics of plant species. Folia Primatologica, 74, 33-47.

Lacher, T. J., da Fonseca, G., Alve, C. J., \& Magalhaes-Castro, B. (1981). Exudate-eating, scent-marking, and territoriality in wild populations of marmosets. Animal Behaviour, 29, 306-307.

Lazaro-Perea, C. (2001). Intergroup interactions in wild common marmosets, Callithrix jacchus: territorial defence and assessment of neighbours. Animal Behaviour, 62, 11-21.

Lazaro-Perea, C., Castro, C. S. S., Harrison, R., Araujo, A., Arruda, M. F., \& Snowdon, C. T. (2000). Behavioral and demographic changes following the loss of the breeding female in cooperatively breeding marmosets. Behavioral Ecology and Sociobiology, 48, 137-146.

Lazaro-Perea, C., Snowdon, C. T., \& Arruda, M. D. (1999). Scent-marking behavior in wild groups of common marmosets (Callithrix jacchus). Behavioral Ecology and Sociobiology, 46, 313-324.

Lazaro-Perea, C., Snowdon, C. T., \& Santee, D. P. (1997). Competition and chemical communication in wild groups of common marmosets (Callithrix jacchus). Annals of the New York Academy of Sciences, 807, 534-537.

Macdonald, D. W. (1985). The carnivores: Order Carnivora. In R. E. Brown \& D. W. Macdonald (Eds.), Social odours in mammals (pp. 619-722). Oxford: Clarendon Press.

Martin, P., \& Bateson, P. (1993). Measuring behaviour - an introductory guide. Cambridge: Cambridge University Press.

Miller, K. E., Laszlo, K., \& Dietz, J. M. (2003). The role of scent marking in the social communication of wild golden lion tamarins, Leontopithecus rosalia. Animal Behaviour, 65, 795-803.

Mykytowycz, R., Hesterman, E., Gambale, S., \& Dudzinski, M. (1976). A comparison of the effectiveness of the odors of rabbits, Oryctolagus cuniculus, in enhancing territorial confidence. Journal of Chemical Ecology, 2, 13-24.

Palagi, E., \& Norscia, I. (2009). Multimodal signalling in wild Lemur catta: economic design and territorial function of urine marking. American Journal of Physical Anthropology, 139, 182-192.

Peres, C. A. (1992). Consequences of joint-territoriality in a mixed-species group of tamarin monkeys. Behaviour, 123, 220-246.

Roberts, S. C., \& Dunbar, R. I. M. (2000). Female territoriality and the function of scent-marking in a monogamous antelope (Oreotragus oreotragus). Behavioral Ecology and Sociobiology, 47, 417-423. 
Roberts, S. C., \& Lowen, C. (1997). Optimal patterns of scent marks in klipspringer (Oreotragus oreotragus) territories. Journal of Zoology (London), 243, 565-578.

Ropartz, P. (1968). The relation between olfactory stimulation and aggressive behaviour in mice. Animal Behaviour, 16, 97-100.

Rylands, A. (1985). Tree-gouging and scent-marking by marmosets. Animal Behaviour, 33, 1365-1367.

Rylands, A. B. (1990). Scent marking behaviour of wild marmosets, Callithrix humeralifer (Callitrichidae, Primates). In D. W. MacDonald, D. Mueller-Schwarze, \& S. E. Natynczuk (Eds.), Chemical signals in vertebrates (pp. 415-429). Oxford: Oxford University Press.

Smith, A. (2000). Interspecific differences in prey captured by associating saddleback (Saguinus fuscicollis) and moustached (Saguinus mystax) tamarins. Journal of Zoology, (London), 251, 315-324.

Temeles, E. J. (1994). The role of neighbors in territorial systems: when are they dear enemies? Animal Behaviour, 47, 339-350.

Terborgh, J. (1983). Five new world primates: A study in comparative ecology. Princeton, NJ: Princeton University Press.

Waser, P. M., \& Wiley, R. H. (1979). Mechanisms and evolution of spacing in animals. In P. Marler \& J. G. Vandenbergh (Eds.), Handbook of behavioral neurobiology (pp. 159-223). New York: Plenum Press.

Washabaugh, K., \& Snowdon, C. T. (1998). Chemical communication of reproductive status in female cotton-top tamarins (Saguinus oedipus oedipus). American Journal of Primatology, 45, 337-349.

Ziegler, T. E., Epple, G., Snowdon, C. T., Porter, T. A., Belcher, A. M., \& Kuderling, I. (1993). Detection of the chemical signals of ovulation in the cotton-top tamarin, Saguinus oedipus. Animal Behaviour, 45, 313-322. 